\title{
Palabras de Juan Rulfo sobre el Comal. Imágenes míticas, desvelos y relaciones precortesianas en Pedro Páramo
}

The Words of Juan Rulfo on Comal. Mythical Images, Concerns, and Pre-Cortés Relationships in Pedro Páramo

Palavras de Juan Rulfo sobre o Comal. Imagens míticas, desvelos e relações precortesianas em Pedro Páramo

\section{Miguel Rocha}

THE UNIVERSITY OF NORTH CAROLINA, CHAPEL HILL, ESTADOS UNIDOS

Candidato doctoral en The University of North Carolina, Chapel Hill.

Magíster en Ciencias Sociales, CBC-FLACSO, Ecuador. Ha ganado

dos becas nacionales de investigación en literatura y el Premio

Nacional de Investigación en (Colombia). Entre sus obras literarias pueden destacarse: El héroe de nuestra imagen (Universidad de los Andes, 2004), Perumanta qanchis aswan allin willakuyna (Norma, 2005), Interacciones Multiculturales (editor) (Universidad Externado, 2008), Antes el amanecer (comp.) (Ministerio de Cultura, 2010), El sol babea jugo de piña (comp.) (Ministerio de Cultura, 2010), Flores del diamante (Oamti, 2010), Pütchi Biyá Uai, precursores (ed.) (Alcaldía de Bogotá, 2011) y Palabras mayores, palabras vivas (Taurus, 2010/2012). Correo electrónico: nem125@yahoo.com 


\section{Resumen}

En el presente artículo se analiza

la novela Pedro Páramo del escritor mexicano Juan Rulfo a partir de simbolismos de origen prehispánico así como de expresiones características del imaginario católico colonial hispánico. El estudio busca profundizar en diversas concepciones sobre la vida y la muerte, la sonrisa y la culpa, las cuales han sido reelaboradas por el novelista en un contexto cuyo substrato de creencias posee notables elementos de las cosmovisiones indígenas. El análisis procura profundizar en el simbolismo del comal, o plato de barro que se usa para la cocción de las tradicionales tortillas de maíz. El comal, en tanto utensilio de origen precortesiano, es analizado como símbolo del mundo mítico rural que acapara Pedro Páramo, gran señor del pueblo de Comala.

Palabras clave: literatura latinoamericana; simbolismo; mitologías prehispánicas; estudios literarios indígenas

\section{Abstract}

In this article we analyze the novel Pedro Paramo of Mexican writer Juan Rulfo, from symbolisms of pre-Hispanic origin, as well as expressions characteristic of the colonial catholic Hispanic imagery. The study aims to expand certain concepts about life and death, smiles and guilt, which have been remade by the novelist in a c0ntext with an underlying foundation of beliefs that has significant elements of indigenous world views. The analysis tries to expand on the symbolism of Comal, the clay dish used for cooking the traditional flat maize pancakes. The Comal, as a tool of PreCortés origin, is analyzed as a symbol of the mythical rural world that Pedro Paramo owns, as great chief of the town of Comala.

Keywords: Latin-American literature; symbolism; preHispanic mythologies; indigenous literary studies

\section{Resumo}

No presente artigo e analisado o romance Pedro Páramo

do escritor mexicano Juan Rulfo a partir de simbolismos de origem pré-hispânica assim como de expressões caraterísticas do imaginário católico colonial hispânico. $\mathrm{O}$ estudo visa aprofundar em diversas concepções sobre a vida e morte, o sorriso e a culpa, as quais foram reelaboradas pelo romancista em um contexto cujo substrato de crenças possue notáveis elementos das cosmovisões indígenas. A análise visa aprofundar no simbolismo do comal, ou prato de barro usado para a cocção das tradicionais tortilhas de milho. O comal, em tanto utensílio de origem precortesiana, é analisado como símbolo do mundo mítico rural que captura Pedro Páramo, grande senhor do povo de Comala.

Palavras-chave: literatura latinoamericana; simbolismo; mitologías prehispánicas; estudios literarios indígenas

RECIBIDO: 25 DE AGOSTO DE 2014. ACEPTADO: 29 DE SEPTIEMBRE DE 2014. DISPONIBLE EN LÍNEA: 01 DE JULIO DE 2015

\section{Cómo citar este artículo:}

Rocha, Miguel. "Palabras de Juan Rulfo sobre el Comal. Imágenes míticas, desvelos y relaciones precortesianas en Pedro Páramo". Cuadernos de Literatura 19.38 (2015): 279-292. http://dx.doi.org/10.11144/Javeriana.cl19-38.pjrc 
Desde SU PUBLiCACión en 1955, la novela Pedro Páramo de Juan Rulfo se convirtió en un clásico de la literatura latinoamericana. Desde entonces la primera y única novela del escritor mexicano se ha convertido en toda una tradición de la palabra y ha alcanzado resonancia mundial mediante adaptaciones teatrales, emisiones radiales, traducciones a medio centenar de lenguas del mundo, páginas web que la celebran y difunden, incontables artículos críticos y escritores de todo el planeta que le reconocen una profunda influencia, como el nobel colombiano Gabriel García Márquez, quien afirmó en 1978: "Si yo hubiera escrito Pedro Páramo no me preocuparía ni volvería a escribir nunca en mi vida" (García Márquez 94).

El propósito del presente artículo es analizar algunas imágenes del sueño, la muerte, la sonrisa, los murmullos, la culpa y el axis mundi. Los puntos de partida son algunas relaciones precortesianas, ciertos elementos del imaginario católico popular y la imagen del comal, o plato de barro mesoamericano, útil para la cocción de las tradicionales tortillas de maíz.

\section{Literatura oral, murmullos, sueños, ecos, psicofonías}

Rulfo escribió la novela Pedro Páramo con el apoyo de una beca del Centro Mexicano de Escritores entre 1953 y 1954 y la publicó parcialmente en revistas en 1954. En marzo de 1955 apareció su primera edición. La obra está dividida en 69 fragmentos narrativos. Rulfo pensó llamarla Los murmullos. En efecto, uno de los principales rasgos de la novela es la polifonía de voces, característica de la vanguardia literaria del siglo XX. Esta técnica narrativa fue usada magistralmente por el escritor jalisciense, cuyos personajes-voces, además de poseer toda la riqueza del lenguaje coloquial mexicano, murmuran a los oídos del lector desde diferentes planos temporales. En Pedro Páramo se trata de personajes muertos que parecieran hablarnos desde nuestros temores, prejuicios, deseos y sueños más profundos.

Las fuentes preliterarias de estas voces, murmullos y ecos, pueden rastrearse parcialmente en el impacto que le causó a Rulfo regresar al pueblo en donde había vivido treinta años atrás. El pueblo estaba deshabitado.

La gente se había ido, así. Pero a alguien se le ocurrió sembrar de casuarinas las calles del pueblo. Y a mí me tocó estar allí una noche, y es un pueblo donde sopla mucho el viento, está al pie de la Sierra Madre. Y en las noches las casuarinas mugen, aúllan. Y el viento. Entonces comprendí yo esa soledad de Comala, del lugar ese" (Pedro Páramo 18). 
Este encuentro abigarrado con el pueblo deshabitado, en lo que Octavio Paz ya había llamado El Laberinto de la Soledad, ensayo publicado unos años antes en 1950, parece ser definitivo en el génesis de la misteriosa obra. Juan Preciado, como Rulfo, regresa al pueblo de su padre muerto. Juan Preciado, como Rulfo, pasa una primera noche en el pueblo "deshabitado", muerto de miedo. El viento es un personaje central en la novela y en la historia del regreso de Rulfo al pueblo. El viento disemina los aullidos, los mugidos y los murmullos de los muertos, aquellos que ya se han ido pero que continúan habitando la memoria. Los murmullos que lleva el viento, los mugidos y aullidos que generan de noche las casuarinas, parecen ser resonancias psíquicas, voces como las que se pueden escuchar en los sueños; psicofonías, como prefieren llamarlas los estudiosos de los fenómenos paranormales del sonido.

Ahora bien, Comala no es el San Gabriel de la infancia de Rulfo, así como Macondo no es la Aracataca nativa de García Márquez. Comala y Macondo son creaciones simbólico-literarias, comarcas orales de la palabra escrita en cuyas páginas-calles el tiempo transcurre con sus propias reglas gramaticales y semánticas. Comala, el pueblo de Pedro Páramo, concentra la carga anímica y simbólica de toda una colectividad. A la vez, Comala es mucho más que el miedo y la nostalgia que produce a Rulfo el encuentro personal con su pasado. Comala pareciera estar escrita a imagen y semejanza del purgatorio descrito por el imaginario católico. Comala arde sobre las brasas de la tierra, como si estuviera a punto de ser tragada por el infierno y sus personajes se pudren carcomidos por gusanos sin nombre, pero con culpa. Los personajes-voces de Pedro Páramo son aparecidos irredentos, caídos y desvanecidos. El pueblo "está lleno de ánimas; un puro vagabundear de gente que murió sin perdón y que no lo conseguirá de ningún modo" (Pedro Páramo 12).

Con el paso de las páginas, la fragmentación narrativa y el desvanecimiento del tiempo nos conducen como lectores a una especie de demencia senil en cuya dimensión los tiempos, imágenes y recuerdos de todas las voces se contraponen, brotan, desaparecen, reaparecen. La novela se puebla no solo de personajes-voces, historias fragmentarias e ires y venires, sino ante todo de sombras, "semioscuridades o penumbras" (Aníbal González 158). Estos claroscuros narrativos remiten anímicamente a las pinturas negras del pintor español Francisco de Goya (17461828), pues nos confrontan con gestos macabros, angustia frente a la muerte y con el presentimiento del fin. La novela nos ensombrece con sus claroscuros, nos ensordece con tantas voces, nos confunde porque no hay un rumbo fijo, en suma: nos liquida como lectores acostumbrados a un orden secuencial y a unas referencias internamente menos perturbadoras. Solo "la lluvia amortigua los ruidos" (Pedro Páramo 144). 
Los murmullos desdibujan los personajes convirtiéndolos en bocetos, en fantasmas, en meros chismes y habladurías. Pueblo pequeño, infierno grande. El propio narrador muere del susto: "Es cierto, Dorotea. Me mataron los murmullos" (El llano 117).

Transgredidos los límites ordinarios de la realidad, incluso ficcional, en donde la gran mayoría de los personajes y voces de una novela "terminan" con su muerte, como en la vida misma, entramos de lleno en el terreno del mito y de los sueños, o del inconsciente colectivo como preferirían llamarlo los estudiosos de la psicología profunda.

Una de las características de los sueños es justamente que podemos experimentar una dimensión diferente del tiempo. El tiempo de los sueños no encaja con el tiempo de la vigilia. La maestría narrativa de Rulfo con respecto al tiempo psicológico de la novela podría resumirse en menos de dos líneas: "El reloj de la iglesia dio las horas, una tras otra, una tras otra, como si se hubiera encogido el tiempo" (Pedro Páramo 77). La repetición, tan característica del lenguaje onírico y ritual; el reloj como mecanismo temporal de la mente moderna; la iglesia como institución medieval y colonial; y el símil de la hora que se da, que se da, que se da para simbolizar una contracción del tiempo y por tanto, cimentar un universo temporal con sus propias leyes.

Así pues muertos todos los personajes, fragmentadas las secuencias narrativas y esbozada una temporalidad diferenciada, nuestras habilidades como lectores alfabetizados se desplazan del azul racional al púrpura intuitivo y debemos apelar a una sensibilidad semejante a la que brota intuitivamente al tener o narrar un sueño, así como a la extrañeza y fascinación que nos produce en primera instancia el relato mítico de otra época o cultura.

Rulfo nos confronta con nuestros sueños. Participamos de la novela como lectores de una narrativa de sueños que nos repele y atrae al mismo tiempo. La novela toca una de las fibras más sensibles de los seres humanos: nuestro innegable miedo a la muerte. E inevitablemente resurgen preguntas como: ¿qué es la muerte? ¿Qué pasa después de la muerte? De allí que a pesar de las dificultades típicas en la lectura de una obra de vanguardia, la lectura de Pedro Páramo tiende a volverse un laberinto en el que el lector desea entrar, para buscar salir, como en los mitos tradicionales, con una posible respuesta existencial. La atracción suele vencer a la reacción y la novela se vuelve un reto al lector que acepta la soledad que usualmente implica el acto de leer.

Pero si los narradores y personajes-voces están muertos, uno podría preguntarse con Gustavo Martínez (78) si los lectores de Pedro Páramo "poseemos la perturbadora condición de difuntos [...] o, cuando menos, de alucinados". 
De acuerdo con este crítico, la idea viene de Borges, quien ha postulado "que si los personajes de ficción pueden ser, a la vez, lectores o espectadores de ella, entonces el propio público de la obra podría ser ficticio" (Martínez 78). Resurge entonces la pregunta sobre qué es real y si la vida es sueño como sugería Calderón de la Barca en el XVII. Con todo, fue César Vallejo quien desde su poética plena de voces afirmó en uno de sus poemas: "Estáis muertos. Qué extraña manera de estarse muertos. Quienquiera diría no lo estáis. Pero, en verdad, estáis muertos". (Vallejo 213). Rulfo va más allá de una afirmación poética y con Pedro Páramo nos pone de cara, de oídos y de letras con la muerte.

\section{Incertidumbre y fatalidad}

La lectura de Pedro Páramo es un encuentro inevitable con la muerte, así como con nuestros temores, deseos, sueños... es una cita con una parte significativa de nuestro inconsciente colectivo, entendido como dimensión profunda de nuestros sentidos, imágenes, instintos y experiencias colectivas como especie. Al mismo tiempo leer Pedro Páramo es remontarse a los orígenes, como Juan Preciado que va en busca de su padre desconocido para reclamar lo que le pertenece.

Pedro Páramo personifica al cacique tradicional latinoamericano, un tipo de señor feudal que acapara la tierra, la comida, la fuerza de trabajo y la gente que trabaja. Pedro Páramo es el dueño del pueblo y de sus mujeres y como mero macho, tiene hijos por todo lado. Con todo, Miguel Páramo es su verdadero sucesor, pues actúa a imagen y semejanza del padre. Con la muerte de Miguel Páramo comienza el derrumbe del padre cacique.

La palabra cacique es de origen indígena antillano y originalmente era usada por los taínos para referirse a un jefe notable. Ahora bien, desde una perspectiva mítica indígena, la figura de Pedro Páramo podría corresponder a la figura atemorizante del Dueño de la Naturaleza, un personaje arquetípico que suele acaparar la comida, el agua o los animales. Con todo, para ser más precisos, Pedro Páramo actúa en realidad como "Señor del paraje de los muertos", un atributo que se le otorgaba en tiempos prehispánicos a Mictlanteuctli, deidad nahua del inframundo que acaparaba no más ni menos que los huesos de la especie humana. Pedro, en tanto cacique, jefe o tlahtoani del desolador páramo de los muertos es, como insinuaba Rulfo, el clásico terrateniente criollo aferrado a las tierras que sus antepasados le arrebataron a los indios, a quienes mandaron para la sierra, para lo yermo y sobre todo: para el olvido.

Pedro Páramo es Señor de los Muertos, y como tal carga con ellas y con ellos, aunque en ese estado ya no importa quién es qué o para qué. Como el 
Mictlanteuctli azteca, Pedro Páramo acapara los huesos de los muertos en ese inframundo que es Comala.

Juan Preciado va a Comala no solo en busca del padre, sino de la madre: "Allí me oirás mejor" (Pedro Páramo 7o). Sin embargo, no sale de allí, queda atrapado por los murmullos y se muere del susto. Juan Preciado deviene entonces en héroe frustrado, en héroe caído, cual Adán; se convierte en antípoda de un héroe resurrecto como Cristo, o capaz de salirse con la suya como Quetzalcóatl, la Serpiente Emplumada. En el Mito de los soles, un ciclo mítico mexica vinculado con el Códice Chimalpopoca (León-Portilla 68), Quetzalcóatl, célebre divinidad azteca y mesoamericana, desciende al Mictlan (región de los muertos) y roba a Mictlanteuctli los huesos de la humanidad. Quetzalcóatl resuscita a los muertos, vuelve a la vida a los seres humanos derramando sangre de su pene sobre los huesos. Se convierte así en salvador y progenitor de la humanidad. En cambio, Juan Preciado no se puede salvar a sí mismo y muere sin poder regresar al lugar de donde vino. Cae como Quetzalcóatl en un pozo, pero de allí no sale, porque ese pozo es su propia tumba. De otro lado, Pedro Páramo carece del poder auto-sacrificial de Quetzalcóatl, quien pasa de ser dueño temporal de los huesos a progenitor de la humanidad. Pedro Páramo no sangra su pene ni su lengua, un acto común de los sacerdotes mesoamericanos, sino que es "sangrado" por uno de sus tantos hijos irredentos, Abundio Martínez, quien lo apuñala borracho ante la desesperación de no conseguir cómo enterrar decentemente a su esposa.

$\mathrm{Al}$ igual que Rulfo, los poetas filósofos nahuas del siglo XV dudaban de la realidad de esta vida, alertaban sobre su fugacidad, la comparaban con el sueño y se preguntaban sobre nuestro destino post mortem. Cuacuauhtzin, poeta y cantor nahua se preguntaba:

¿Adónde en verdad iremos

a donde nunca muramos?

(León Portilla 209)

Acomiztli Nezahualcóyotl, el más célebre de los poetas cantores del México antiguo, quien también fue rey o señor de gentes, afirmaba:

"Sólo venimos a dormir, sólo venimos a soñar, no es verdad, no es verdad que venimos a vivir en la tierra".

(Westheim 45) 
Fray Bernardino de Sahagún, el franciscano que más hizo por rescatar la voz y el pensamiento nahua en el siglo XVI, al reflexionar sobre la concepción de la muerte entre los nahuas escribió que le contaron,

$[\ldots]$ que no morían sino despertaban de un sueño en que habían vivido; por lo cual decían los antiguos que cuando morían los hombres no perecían, sino que de nuevo comenzaban a vivir, casi despertando de un sueño, y se volvían es espíritus o dioses. (Westheim 38)

Los personajes-voces de la novela efectivamente van a ese lugar a donde "nunca" se muere, al menos hasta el derrumbe de Pedro Páramo: el Señor de los Muertos. Pero lejos de despertarse de un sueño y aún más lejos de convertirse en dioses, vagan como almas en pena, encadenados a sus culpas, dementes, obsesivos, irredentos... En este punto corroboramos que no estamos en el Mictlan nahua sino en el mero espejo del purgatorio católico. Con todo, en ese claroscuro de imágenes y sensaciones subterráneas que es Comala, la actitud de las almas en pena nos delata que la angustia no es generada por la muerte misma sino por la exposición a Tezcatlipoca, la incertidumbre, la pesadumbre y en suma: la fatalidad. Paul Westheim, historiador del arte alemán, afirmó con profundo conocimiento de las fuentes precortesianas: "El México antiguo no temblaba ante Mictlanteuctli, el dios de la muerte; temblaba ante esa incertidumbre que es la vida del hombre. La llamaban Tezcatlipoca" (Westheim 12).

La iconografía azteca revela a un Tezcatlipoca a quien Cipactli, el cocodrilo que simboliza la tierra, le ha arrancado sin piedad uno de sus pies. Su imagen es la fatalidad misma. De hecho, Tezcatlipoca es el opositor mítico de Quetzalcóatl, a quien en su encarnación histórica de Ce Ácatl (Uno Caña), Señor de Tula, hace caer en una grave falta social al darle una pócima que le privó de sus cabales, hasta el punto de estimularlo a caer en incesto con su propia hermana.

El incesto aparece sugerido en Pedro Páramo, por ejemplo en la relación de Susana San Juan con su padre. El incesto, un pecado mayor en el imaginario católico, y una falta grave en la cosmovisión Tolteca -de acuerdo con la historia de Uño Caña-, aparece como una acción necesaria y no sancionable en numerosos mitos originarios, en donde hermano y hermana, o madre e hijo, o padre e hija, se unen básicamente para que haya descendencia.

Las potencialidades y restricciones filosóficas de las refinadas civilizaciones mesoamericanas sobrevivieron en la población indígena y mestiza que fue sometida a siglos de una nueva moral y visión de mundo impuesta por la Iglesia Católica. Así pues, en Pedro Páramo la fatalidad y la noción de castigo parecen ser el resultado de la confluencia entre distintos sistemas sociales reguladores 
que aún subyacen en los temores más profundos del inconsciente colectivo. En concepto de Westheim:

[...] el mito mexicano, que no conoce el infierno, que no aplaza el castigo del pecador para después de la muerte, expone al hombre a la inseguridad llamada Tezcatlipoca. Siempre, en cualquier momento, debe estar preparado a que el destino lo aplaste. (Westheim 39)

Pedro Páramo, a pesar de su aparente seguridad, tiene presente la fatalidad por venir. Sabe qué vendrá pero no sabe cuándo. Cuando muere su hijo predilecto, Miguel Páramo, reconoce que es mejor comenzar a pagar temprano. Pedro Páramo "tenía miedo de las noches que le llenaban de fantasmas en la oscuridad. De encerrarse con sus fantasmas. De eso tenía miedo" (Pedro Páramo 178). Las muertes de Miguel Páramo y Susana San Juan son fatalidades que anuncian el derrumbe final de Pedro Páramo.

\section{Doña Comala}

Juan Rulfo no especula ni infiere como los filósofos y poetas nahuas. Nos traslada con el poder de su narrativa a ese lugar/destino post mortem, que no es propiamente el Mictlan, ni el cielo ni el infierno. Es Comala a secas.

Comala, ese "purgatorio a ras de suelo", como decía Mario Benedetti, es un pueblo arruinado, con hambre, en donde todos están muertos pero siguen viviendo y sufriendo en este valle de lágrimas. Comala es como una estampita recortada de la Virgen del Carmen, en donde solo queda el purgatorio, las llamas, la gente, pero desaparece el socorro de la virgen hada. Sus habitantes son como "sepulcros blanqueados", y el padre Rentería parece inoperante, está sometido al poder del cacique, y representa una iglesia que "no entra ni deja entrar". A decir de Abundio, el arriero que conduce a Juan Preciado, Comala está ubicada "sobre las brasas de la tierra, en la mera boca del infierno" (Pedro Páramo 67).

Ahora bien, aunque el lenguaje coloquial usado por Rulfo en la novela está cargado de palabras provenientes del náhuatl, como papalotes, milpa y petaca, Comala es diferente de Apango, el pueblo de donde descienden los indios a comerciar". El nombre de Comala "proviene del topónimo náhuatl comalli, que Molina define así: "comal a donde cuecen tortillas de maíz" Comala significa

1 En México existe una ciudad de nombre Comala, "a diez km al norte de la capital del estado de Colima, en una región en que habitaron olmecas, nahoas, toltecas, chichimecas y tarascos. Hay aún hablantes del náhuatl en algunas partes del municipio. Como pueblo de indios sujeto a encomienda, Comala existió ya en los primeros años posteriores a la conquista española" (López Mena 62). 
"lugar donde se fabrican comales" (López Mena 62). El comal es un plato de barro usado para cocinar, que en algunas regiones amazónicas se conoce como budare. En tanto utensilio de cocina para la cocción de los alimentos, en particular tortillas, arepas y panes de yuca brava, es un atributo de civilización tan importante como el caldero chino o celta. El comal es el mediador entre el fuego y el hombre, es el lugar de transformación de lo crudo a lo cocido. En tal sentido simboliza el lugar nutricio original y junto con el fogón o el fuego del hogar, se torna en espacio privilegiado para la palabra y por tanto en axis mundi.

De vuelta a la leyenda o Mito de los soles, los huesos robados en el Mictlan son llevados a Tamoanchan, paraíso nahua de la abundancia en donde son molidos en el metate por la gran madre terrible, quien los deposita en una vasija de jade (León Portilla 75). Esta vasija es receptáculo de la masa de huesos, así como el comal acoge la masa de maíz que se convertirá en tortillas y totopos. Quetzalcóatl sangra sobre la masa y luego los dioses le siguen con sus sacrificios o merecimientos. La masa de huesos es fecundada con sangre. Pedro Páramo, cual anti-dios, como un Goliat de piedra, acapara su propia sangre, aunque chupa la de todos. Como mero macho succiona metafóricamente la leche de las incontables mujeres de su rebaño. Al final Abundio, un borracho, un "cualquiera", un David anónimo, pero también su hijo, le arranca el primer chorrito de sangre. Y el cacique comienza a desangrarse, a derrumbarse.

El comal es axis mundi, caldero y vasija en donde se cuece "la leche esencial" del maíz transformado en comida, en palabra -y en carne si pensamos en el origen de la humanidad de acuerdo con el Popol Wuj maya-. El Comala fundacional, no el derruido, pudo haber sido un paraíso nutricio, un Tamoanchan, un lugar de origen, una tierra en plena madurez. Y para Juan Preciado lo es, antes de los anuncios fatalistas de Abundio, el arriero. Juan Preciado se encamina a Comala en búsqueda de sus orígenes. Pero si Comala fue paraíso, cayó, fue arrojado con todo y gente. Sus pecados y culpas lo hundieron en el abismo, dejándolo acostado como un metate sucio en las puertas del infierno.

Apango, el pueblo de indios, a pesar de las recurrentes amenazas coloniales de castigos, purgatorios y caídas en el infierno, queda y quedó más arriba de Comala. Los indígenas bromean, ríen en Pedro Páramo. El que ríe de último ríe mejor. Andan en grupo. Comercian con lo poco que tienen. Le dejan limosna a la virgen. Son diferentes básicamente porque les da risa. Esa risa y no las lágrimas con que los pinta el indigenismo oficial, revela su diferencia cultural y devela su dignidad. En Pedro Páramo los indígenas no lucen sometidos a la culpa mental-emocional del pecado impuesto por la religión dominante. Para ellos en la anegada Comala solo es un mal día, no una eternidad. Se persignan, tiemblan, 
tienen frío, les falta el pulque. No son almas en pena y aunque puede que tengan las suyas, sonríen, muestran los dientes como el mexicano al comerse las calaveras de dulce en el día de los muertos. La actitud respetuosa pero irreverente ante la muerte, tal vez sea uno de sus legados más preciosos. Sin embargo, si todos están muertos en la novela, si todos son ecos y voces e imágenes sueltas, entonces los indígenas que bajan de Apango a Comala tienen que ser otra cosa, al menos espíritus y no almas en pena. Cuando echan chistes y sonríen nos recuerdan a los dioses. No son inmortales pero sonríen, muestran los dientes, creen.

\section{Desdramatización e irreverencia}

La muerte de Susana San Juan, mujer de Pedro Páramo, es el evento definitivo que influye en la liberación de Comala de su cacique opresor. Esta liberación consiste ante todo en la desdramatización de la pesada atmósfera mortuoria.

Todas las campanas repican incesantemente para anunciar el luto y magnificar el dolor de Pedro Páramo.

Llegó el mediodía y no cesaba el repique. Llegó la noche. Y de día y de noche las campanas siguieron tocando, todas por igual, cada vez con más fuerza, hasta que aquello se convirtió en un lamento rumoroso de sonidos. Los hombres gritaban para oír lo que querían decir (Pedro Páramo 170).

El lamento muta en carnaval, pues:

[...] comenzó a llegar gente de otros rumbos, atraída por el constante repique. De Contla venían como en peregrinación. Y aun de más lejos. Quién sabe de dónde, pero llegó un circo, con volantines y sillas voladoras. Músicos. Se acercaban primero como si fueran mirones, y al rato ya se habían avecindado, de manera que hasta hubo serenatas. Y así poco a poco la cosa se convirtió en fiesta. Comala hormigueó de gente, de jolgorio y de ruidos, igual que en los días de la función en que costaba trabajo dar un paso por el pueblo (Pedro Páramo 171).

Hasta un circo llegó. El pueblo le había dado la espalda a Pedro Páramo, desentendiéndose de su pena. Pedro Páramo afirmó: "Me cruzaré de brazos y Comala se morirá de hambre" (Pedro Páramo 171).

La escena del incesante repicar de las campanas y de la muerte que se transforma en fiesta, no solo es eficaz para referirse a la religiosidad popular mexicana, sino que anticipa con plenitud la hipérbole característica del realismo mágico. El pesimismo agonizante del pueblo, la pesadez mortuoria de sus personajes-voces, se resuelve con la liberación por la fiesta y por la risa, la borrachera y la música, 
y en últimas mediante la doble irreverencia frente al poder tiránico del cacique y la culpa pecaminosa irradiada por la religión dominante. Puede sugerirse que una vez huido el padre Rentería a la guerra de rebelión cristera, la figura de Pedro Páramo termina de absorber la piedra fundacional de la iglesia que representa el apóstol Pedro. Por eso todas las campanas sonaban a su favor. Es entonces cuando su peso se torna insoportable. Pedro, convertido en un gigante de piedra que acapara los alimentos, quiere vengarse de sus propios muertos. Para entonces su presencia concentra tres figuras paternales de autoridad: el Papa, el papá y el Cacique. De fecundador y dictador deviene en autoridad suprema. Y aunque todos están muertos, quiere castigarlos, quiere dejarlos que se mueran de hambre. Se cruza de brazos. El comal de cómala se queda sin tortillas.

\section{Comal-a-dentro. A modo de Conclusión}

En numerosas cosmovisiones indígenas, no solo la nahua, la vasija y/o el plato de barro para cocinar (comal, budare, etc.) es símbolo del mundo. Se trata de una imagen simbólicamente próxima a la Media Luna, tierra abarcada por Pedro Páramo. El comal tradicional se sostiene "sobre tres o cuatro piedras (llamadas tenamaxtles), que sirven para darle soporte y para poder encender fuego y brasas debajo" (Wikipedia). Las tortillas de maíz, totopos y tlayudas crepitan con las llamas mientras se cocinan sobre el comal. El conjunto que crepita sonoramente es el fogón, axis mundi familiar y central para indígenas, campesinos y ciertos sectores de la población urbana en Hispanoamérica. Por ejemplo, en algunas comunidades indígenas andinas, debajo del fogón se suele enterrar la placenta y/o el cordón umbilical. El fogón es el lugar nutricio y cálido por naturaleza. Es la madre. Es el origen. Es el lugar placentero, es decir: donde está la madre, la placenta. Es el lugar: place en inglés.

El fogón, aquí por extensión comal, es continuación del paraíso original que palpita desde el vientre de la madre. La madre le dice a Juan Preciado: "Allí me oirás mejor. Estaré más cerca de ti" (Pedro Páramo 7o). Y Juan sigue esa voz hasta Comala. El sonido originario, placentero y nutricio de la madre, de la tierra, del comal, encuentra su antípoda en Susana San Juan, la desterrada hija de Eva, quién aunque ya está muerta tiene que volver a morir. Para la agonizante, atemorizada, loca, delirante mujer de Pedro Páramo, la vida es una carga impuesta, es pena, es dolor. Ella escucha crujir la tierra, hundirse sus abismos, parir con dolor. El "fuego del comal" es para ella brasa e infierno; no redención, ni menos cocción o nutrición. Susana pregunta: " ¿iY qué crees que

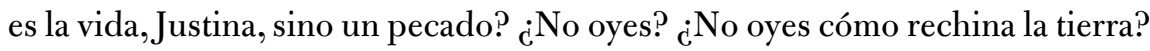
(Pedro Páramo 164) 
Al morir Pedro Páramo "dio un golpe seco contra la tierra y se fue desmoronando como si fuera un montón de piedras" (Pedro Páramo 164). El comal se quedó sin sus piedras de soporte. Comala terminó de morirse de hambre. O tal vez no. Quizás fue todo lo contrario. El derrumbamiento del pretendido dios, después de su muerte definitiva, habrá servido como el sacrificio aplazado, distanciado del centro, al menos para liberar a las almas en pena de su demencia senil.

Para Jorge Aguilar Mora, "la novela de Pedro Páramo es nada menos que la trasformación de un símbolo en su materia; y en este sentido es todo lo contrario del proceso mítico cristiano y de todo proceso mítico" (Aguilar Mora 11). No obstante, el derrumbamiento en piedra también podría dejar abierta la cuestión mítica del castigo mediante la conversión en piedra, la litomorfosis, un motivo común en los imaginarios indígenas. Debe tenerse en cuenta que en el imaginario judeo-cristiano las piedras son símbolo del pecado; con ellas se solía castigar a los pecadores mediante el linchamiento.

Cuando las piedras de Pedro Páramo se desmoronan, él es el único que realmente muere del todo. Es posible esperar cierta liberación cuando Comala cae del todo, como un comal que se hunde sobre las piedras y brasas y llamas de su propio fogón. Quizás Comala se redima al consumirse en las llamas purificadoras del purgatorio o del infierno. $\mathrm{O}$ tal vez todo vuelva a un punto cero, mineral, inerme, como las meras piedras secas sobre la costra de tierra polvorienta. Y las nubes cargadas de lluvia. En cualquier caso Pedro Páramo es un mundo que se derrumba antes que un personaje que cae. El final de la novela, como todo símbolo profundo, queda abierto a la imaginación.

\section{Obras citadas}

Aguilar Mora, Jorge. "El silencio de Nellie Campobello", Cartucho: relatos de

la lucha en el norte de México. México D.F: Ediciones Era, 2005, 9-43.

Estrada, Julio. El sonido en Rulfo: "el ruido ese". México: UNAM, 2008.

García Márquez, Gabriel. "El oficio de escritor". Fuan Rulfo, otras miradas. Víctor Jiménez, Julio Moguel y Jorge Zepeda

Eds. México: Fundación Juan Rulfo, 2011. 91-94.

León-Portilla, Miguel. Antigua y nueva palabra. México: Aguilar, 2004.

López Mena, Sergio. Diccionario de la obra de fuan Rulfo. México: UNAM, 2007.

Martínez, Gustavo. Fuan Rulfo, perspectiva mítica y técnica narrativa

en Pedro Páramo. Montevideo: Rebeca Linke Editoras, 2008.

Jiménez, Víctor; Julio Moguel, y Jorge Zepeda, Eds. Fuan Rulfo.

Otras miradas. México: Fundación Juan Rulfo, 2011. 
Jiménez, Yvette, y Luzelena Gutiérrez Eds. Pedro Páramo, diálogos en contrapunto. México: Colegio de México, 2008.

Rulfo, Juan. El llano en llamas y otros cuentos. México: F.C.E, 1953.

-.Pedro Páramo. Edición y estudio crítico de José Carlos

González Boixo. Madrid: Cátedra, 2012.

Vallejo, Cesar. Vallejo, poesía completa. Madrid: Ediciones Akal, 2005.

Vital, Alberto, Víctor Zepeda y Jorge Zepeda Coords. Tríptico para

fuan Rulfo. México: Fundación Juan Rulfo, 2006.

Westheim, Paul. La calavera. México: F.C.E., 1953/1985.

Wikipedia. "Comal". Wikipedia. s.f. Disponible en http://es.wikipedia.org/wiki/Comal 